\title{
BACK TO BURGESS: \\ THE IMPACT OF THE WHITE BURGESS \\ EXPERT EVIDENCE REgIMe In Alberta DeCisions
}

\author{
LISA A. SILVER ${ }^{*}$
}

\begin{abstract}
The law on the admissibility of expert evidence was refined in the Supreme Court of Canada's White Burgess decision. While still retaining the Mohan criteria, the Supreme Court further defined the trial judge as an agent of change through an enhanced gatekeeper function. However, all stakeholders in the justice system have a gatekeeper function and must work together when determining the use to be made of evidence. Through surveying Alberta cases involving expert evidence, the author identifies areas where lower courts are applying the new approach and where they do not fully embrace the new approach, but revert back to the traditional Mohan criteria. The author discusses notable themes from recent case law to identify potential future issues involving expertevidence. Although slowly, Alberta courts are applying the new regime, and the focus and direction of expert evidence continue to develop.
\end{abstract}

\section{TABle OF CONTENTS}

I. INTRODUCTION $\ldots \ldots \ldots \ldots \ldots \ldots \ldots \ldots \ldots \ldots \ldots \ldots \ldots$

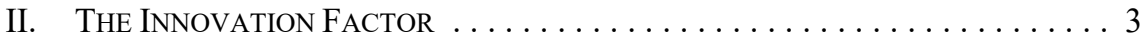

A. The First Principles of Opinion Evidence $\ldots \ldots \ldots \ldots \ldots \ldots$

B. SCOPING OUT THE "SCOPE" $\ldots \ldots \ldots \ldots \ldots \ldots \ldots \ldots \ldots \ldots$

C. The Two-Step Process $\ldots \ldots \ldots \ldots \ldots \ldots \ldots \ldots \ldots \ldots \ldots \ldots$

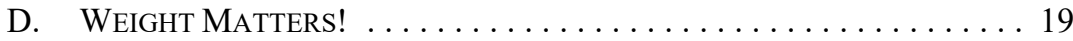

E. Themes of INNOVATION ARISING From CURRENT



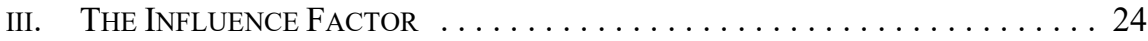

IV. BRINGING IT ALL TOGETHER: CONCLUSIONS

ON THE IMPACT OF THE NEW REgime In AlberTA . . . . . . . . . . . . . 27

\section{INTRODUCTION}

The law on the admissibility of expert evidence and the subsequent application of that law have evolved due to the combined effect of three Supreme Court of Canada decisions: $R$. $v$. Sekhon, ${ }^{1}$ White Burgess Langille Inman v. Abbott and Haliburton Co. ${ }^{2}$ and R. v. Bingley. ${ }^{3}$ They provide a high-level view of the potential powerful effect of expert evidence and the desire of the Supreme Court to restrain and contain that power. In particular, the White Burgess decision synthesizes previous case law and academic scholarship on the issue. It constructs a unique platform in which to apply those traditional and well-accepted rules of evidence. Through this case, the Supreme Court is not altering the landscape as much as it is refining the raw material by articulating a step-by-step approach for both the trial judge

Assistant Professor, University of Calgary, Faculty of Law; BA (Econ UWO); LLB (Osgoode); LLM (Calgary); and of the Bars of Alberta \& Ontario.

2014 SCC 15 [Sekhon].

2015 SCC 23 [White Burgess].

2017 SCC 12 [Bingley]. 
and counsel. ${ }^{4}$ White Burgess is concerned with both principle and practice, but realistically is this seemingly clearly articulated approach having the desired impact? This article will have a twofold purpose. First, it will examine the impact White Burgess is having on subsequent case law in Alberta. Second, it will distill from this recent case law notable themes, which will assist in identifying potential future issues in expert evidence cases.

As mentioned, White Burgess can be viewed as an easy extension from the traditional principles of expert evidence. But White Burgess is tradition with a difference. It is these differences that will serve as indicators of impact throughout the review conducted in this article. In White Burgess, Justice Cromwell deftly overlaid the Supreme Court's enhanced gatekeeper function ${ }^{5}$ onto the admissibility process while still retaining the R. v. Mohan ${ }^{6}$ criteria or, more accurately, the Supreme Court's refined Wigmore criteria, ${ }^{7}$ as a basis for the analytical framework. It is in this enhanced gatekeeper function where the Supreme Court further defines the trial judge as an agent of change.

But an agent cannot work alone. In all three decisions, Sekhon, White Burgess, and Bingley, the Supreme Court gives a clear and convincing caution to the trial judge and also to counsel to be ever vigilant in the admissibility of expert evidence and in the ultimate use of the evidence in the final determination. ${ }^{8}$ This caution is firmly based in the gatekeeper function of the trial judge to maintain and protect the integrity of the justice system. Yet, as seen through subsequent pronouncements from the Supreme Court on the health of that system, specifically in Hryniak v. Mauldin ${ }^{9}$ and R. v. Jordan ${ }^{10}$ it is also anchored in the unifying vision that all of the stakeholders in the justice system have a gatekeeper function. The underlying message is that we must all work together, mindful of the evidence we lead and the decision-making power we hold when determining the use to be made of the evidence. In the context of expert evidence, impermissible admissibility of such evidence can result in a miscarriage of justice and a subsequent diminishment of the confidence in that system to provide a fair and impartial forum for disputes. ${ }^{11}$ Expert evidence is a gateway to which we all must pay heed.

To understand the impact of these cases is to see that impact through lower-court application of those decisions. In this article, I trace the application of the Supreme Court decisions through a survey of recent Alberta cases involving expert evidence issues. ${ }^{12}$ I have done this by focusing on two factors: innovation and influence. In Part II, I will discuss the

Specifically, the Supreme Court is adopting the approach articulated by Justice Doherty of the Court of Appeal for Ontario in $R v$ Abbey, 2009 ONCA 624 [Abbey]. See White Burgess, supra note 2 at paras 22-24.

$5 \quad$ See e.g. $R v$ Bradshaw, 2017 SCC 35 [Bradshaw]; $R v$ Grant, 2015 SCC 9 [Grant]; $R v$ Hart, 2014 SCC 52 [Hart]; $R$ v Rodgerson, 2015 SCC 38.

[1994] 2 SCR 9 [Mohan].

$R v$ Khelawon, 2006 SCC 57 at para 42, citing John Henry Wigmore, A Treatise on the Anglo-American System of Evidence in Trials at Common Law Including the Statutes and Judicial Decisions of All Jurisdictions of the United States and Canada, vol 3, 2nd ed (Boston: Little, Brown and Company, 1923), s 1420. Sekhon, supra note 1 at para 46, Moldaver J, citing Doherty JA in Abbey, supra note 4 at para 62; White Burgess, supra note 2 at para 45; Bingley, supra note 3 at paras 30-32.

2014 SCC 7.

2016 SCC 27.

White Burgess, supra note 2 at para 12.

As of 27 October 2017, there are 37 Alberta cases citing the White Burgess decision. Seventeen of those cases are criminal. Of those 37 cases, 13 are Alberta Court of Appeal decisions with 11 of those decisions being criminal. 
innovation factor, which will identify those areas where the lower courts are applying the new approach. It is in that latter discussion where we glimpse the future evolution and development of expert evidence issues. The influence factor, in Part III of this article, widens the lens of impact as it involves an analysis of how influential White Burgess is by reviewing which cases do not fully embrace the new approach, but instead revert to using the traditional Mohan criteria only.

Finally, in Part IV, I will bring innovation and influence together to ground my hypothesis that the impact of the new regime in Alberta is slow yet steady as the courts, mindful of the new case law, are applying the sentiments of the new regime. On a case-by-case assessment, the impact of White Burgess may not be apparent, however, on review of recent Alberta case law, the focus and direction of expert evidence will not remain static, but will continue to be an area of development, which will impact other areas of law.

\section{THE INNOVATION FACTOR}

Innovation, or the creation of new methods and approaches, is a key indicator of law making. We are part of a common law tradition that leans on continuity with the past through the application of precedent. Precedent is stability and allows us to understand the law and the reasoning behind it. The common law, however, is not static, but is continually regenerated through a factual matrix reflecting today's concerns and issues. The law must be flexible enough to adapt to new real-life situations, but must also be coherent with our past if it is to have any credibility with the public. Public confidence and the integrity of the justice system are core values of the law. The creation of new approaches to the law can happen at any level of court, but it is at the Supreme Court, the final repository of Canadian legal principles, where long-term innovation happens. The Supreme Court will innovate, but then the lower courts disseminate. How quickly this dissemination happens and how effectively are difficult measurements to make.

In this Part, I will look at how the Alberta courts have used the new approach and for what purpose. Innovation is meaningless unless it sparks further conversation and further innovation and is responsive to the specific issues arising in a specific case or is reflective of practice in a particular jurisdiction. I have chosen Alberta as the laboratory for this search for innovation.

I propose to approach this innovation discussion by viewing recent cases through the lens of both the basic rules behind the admissibility and use of expert evidence and the White Burgess expert evidence regime. First, before launching into the current state of expert evidence principles, we must step back to first principles to understand why expert evidence receives the "Supreme Court" treatment.

\section{A. The First Principles OF Opinion Evidence}

The basic principle of admissibility necessitates that only relevant and material evidence is admitted at trial. There are exceptions. Relevant and material evidence may be excluded due to the operation of another evidentiary rule or through the judicial exercise of the exclusionary discretion. The opinion evidence rule is an exception to this basic principle. According to this rule, witnesses must testify to facts only and not to conclusions based on 
their own inferences. It is the province of the trier of fact to draw reasonable inferences from the evidence in arriving at findings. If opinion evidence from witnesses is accepted, such opinion evidence would usurp the function of the trier of fact. There is a further danger that the witness' conclusions are based on hearsay and not on observable facts. In the words of Wigmore, "the witness must speak as a knower, not merely a guesser."13 To permit such evidence would be contrary to the truth-seeking function of the court. According to Justice Cromwell in White Burgess, opinion evidence was "not helpful" to the trier and "might even be misleading," suggesting the "most convincing" rationale for exclusion of opinion evidence. ${ }^{14}$

The operation of the opinion fact rule is problematic as it is difficult to distinguish fact from opinion or conclusion. As James Thayer noted: "In a sense all testimony to matter of fact is opinion evidence; i.e., it is a conclusion formed from phenomena and mental impressions. Yet that is not the way we talk in courts or in common life. Where shall the line be drawn? When does matter of fact first become matter of opinion?"15

Looking further afield to philosophical debate, Hannah Arendt argued that "[f]acts and opinions, though they must be kept apart, are not antagonistic to each other; they belong to the same realm."

In Graat v. The Queen, the Supreme Court recognized the ability of witnesses to testify to a "compendious statement of facts" and as such give evidence, not because of any expertise or special knowledge, but based on personal knowledge of a set of observable facts. ${ }^{17}$ In this manner, the witness testifies, as many other witnesses do, to an "abbreviated version" of facts that are "too subtle and too complicated to be narrated separately and distinctly." 18

Justice Romaine considered this issue in the 2015 Alberta Court of Queen's Bench decision of Dow Chemical Canada ULC v. Nova Chemicals Corporation..$^{19}$ After a detailed survey of the law, Justice Romaine admitted some of the proposed witness evidence as facts "within their knowledge, observation and experience" and excluded some of the evidence as "impermissible lay opinion." ${ }^{20}$ Similarly, in R. v. Hamilton, the Ontario Court of Appeal found the evidence of the number of cellphone calls and cell tower and cellphone locations was not opinion evidence, but merely facts based on knowledge, observations, and experience..$^{21}$

Expert evidence, as a form of opinion evidence, operates as an exception to the opinion evidence rule and can be considered an exception to an exception. As a form of opinion,

\footnotetext{
13 John Henry Wigmore, Evidence in Trials at Common Law, vol 7, revised ed by James H Chadbourn (Boston: Little, Brown and Company, 1978), s 1917.

Supra note 2 at para 14.

James Bradley Thayer, A Preliminary Treatise on Evidence at the Common Law (Boston: Little, Brown and Company, 1898) at 524.

Hannah Arendt, "Truth and Politics," The New Yorker (25 February 1967).

[1982] 2 SCR 819 at 840 [Graat].

Ibid at 839,841 .

2015 ABQB 401.

Ibid at paras 7, 25

2011 ONCA 399.
} 
expert evidence is presumptively inadmissible, but the expert evidence rule permits admission when certain criteria are fulfilled. Expert evidence does offer conclusions and does provide a "ready-formed" inference..$^{22}$ But it provides an inference that the trier of fact would not otherwise be able to make. Without such expert opinion, there would be a gap in the evidence, which would run contrary to the truth-seeking function of the court. Generally, expert evidence is admissible where the subject matter is outside the knowledge and experience of the trier of fact and where such expert opinion can assist the trier in its final determination of an issue.

Just as it is difficult to draw a line between fact and opinion, it can be difficult to discern opinion from permissible expert opinion. The Graat scenario is a good example. Police officers who testify to their observations on impairment are not speaking as experts on the issue of impairment, but as experienced observers of driving behaviour. This concept of observable facts as opposed to expertise becomes blurred in the Supreme Court's Bingley decision, where Drug Recognition Experts testifying to indicia of drug impairment are deemed experts pursuant to legislation. ${ }^{23}$ Due to this conclusive and irrebuttable presumption of expertise, the Supreme Court declined to comment on the possibility the information was merely lay opinion or non-expert opinion evidence. ${ }^{24}$ Nevertheless, the Supreme Court indicated that the evidence, based on "specialized training and experience," could not be characterized as lay opinion. ${ }^{25}$

Although Bingley appears to be drawing a definitive line between expert and opinion, in fact, Bingley represents a subtle yet real shift away from the old traditional view of what an expert is and what expertise looks like toward a broader approach. In Bingley, the expert quality of the Drug Recognition Expert was not undermined by the witness' lack of training in the underlying science of that expertise. ${ }^{26}$ Read in conjunction with Graat, the Bingley decision offers a halfway-house position wherein an expert is not defined by a rigid construction of their knowledge and background, but by the purpose of their training and experience. This purposive approach to expert identification mirrors the Supreme Court's penchant for flexibility and contextualization in the admissibility of evidence. ${ }^{27}$

The purposive approach to opinion evidence also influences Alberta case law. For instance, experts, as recognized by the Alberta Court of Appeal in Kon Construction Ltd. v. Terranova Developments Ltd., may even be an electronic record ${ }^{28}$ or, as argued in the Alberta Court of Appeal decision of $R$. v. Iyamuremye, a Crown Prosecutor's PowerPoint presentation compiled with the assistance of the investigating officers. ${ }^{29}$ In Iyamuremye, the Court found the presentation was merely an "evidentiary aid." ${ }^{30}$ However, the Court did recognize the possibility that such an aid could "venture into interpretative analysis" and

White Burgess, supra note 2 at para 14.

Supra note 3.

Ibid at para 27.

Ibid at para 34

Ibid at para 22

See e.g. $R v$ Khan, [1990] 2 SCR 531; Bradshaw, supra note 5.

2015 ABCA 249 at paras 22-26 [Kon].

2017 ABCA 276 [Iyamuremye].

Ibid at para 93 . 
become opinion evidence. ${ }^{31}$ In those circumstances, the Court cautioned on the need to enter into an admissibility hearing pursuant to the White Burgess and Bingley decisions. ${ }^{32}$

In practice, the issue of whether the witness is offering expert evidence rather than mere inadmissible opinion evidence (which might be admissible as a compendium of fact) should be conducted before the application of the White Burgess admissibility regime. This recommended approach would ensure a proper legal characterization of the proposed evidence and clarify the use of that evidence, if admissible, under the appropriate rubric. Thus, a preliminary Graat voir dire should be conducted to ensure the essence of the witness' proposed testimony is delineated before entering into what may be an unnecessary expert evidence voir dire. If the evidence is admitted as an abbreviated form of fact, the White Burgess regime is not even engaged. In Alberta, this preferred approach was acknowledged in the 2017 Alberta Provincial Court decision of R. v. Hachem, a case considered more thoroughly below. ${ }^{33}$

Although this is the preferred approach where the preliminary issue is whether the opinion evidence can be considered expert evidence, trial courts tend to deal with the issue contextually and as informed by the White Burgess criteria. For instance, in Primewest Energy Inc. v. Texacana Turbines Inc., Justice Nixon found the evidence of two witnesses on an application to strike was opinion evidence and not expert. ${ }^{34}$ She also specifically found neither of the two witnesses met the White Burgess requirement for independence and impartiality. ${ }^{35}$ As the evidence was conclusionary, it was deemed inadmissible. Justice Nixon, however, went further in her analysis by indicating that even if it was admissible, it was "too general to be helpful." "36 This was a brief application of White Burgess but an effective one. ${ }^{37}$

This distinction between fact, lay opinion, and expert opinion is not an easy exercise as evidenced by recent Alberta cases. In R. v. Sandoval-Barillas, the Alberta Court of Appeal considered the admissibility of the evidence of a defence expert on "change blindness." ${ }^{\text {" }}$ The evidence, if admissible, could impact the victim's identification of the accused as the perpetrator. Although the appellate court agreed with the trial judge that the evidence was inadmissible as it was unnecessary and unhelpful to the trier, the Court's discussion of the legal principles of opinion evidence seem to suggest a relaxation that goes beyond the Graat principle. In Graat, the Supreme Court found the evidence of the police officers on the indicia of impairment was permissible, not because it was opinion evidence per se, but because it was this "form of opinion," which enabled the witness to "more accurately ... express the facts he perceived." ${ }^{39}$ In other words, although in form it was opinion, in fact it was merely an "abbreviated version of the [witnesses"] factual observations." 40

Ibid.

Ibid.

2017 ABPC 186 at para 89 [Hachem].

2016 ABQB 715 [Primewest]. See also Kowalchuk $v$ White, 2018 ABQB 421 at paras 11-13.

Primewest, ibid at para 111 .

Ibid at para 112 .

See also $R v$ Gabruch, 2016 ABPC 5 at para 24.

2017 ABCA 154 at para 55 [Sandoval-Barillas].

Supra note 17 at 835, 837, citing Report of the Federal/Provincial Task Force on Uniform Rules of Evidence (Ottawa: Uniform Law Conference of Canada, 1981).

Ibid at 839 . 
The Court in Sandoval-Barillas extends the concern articulated in Graat by delineating between the police officer testifying as a "lay person" giving observations and an "expert" giving expert evidence. In paragraph 54 of the decision, the Court of Appeal underlines the danger with opinion evidence when "announced by an impressive person," presumably such as the defence expert, which may then receive greater weight than what the probative value of the evidence dictates. ${ }^{41}$ In Graat, the Supreme Court was more concerned with separating the police officer, as a person in authority, from the factual observations given in the testimony to ensure the trier of fact did not give the officer, in those circumstances, any "special regard." 42 In other words, Graat is a decision on the distinction between fact and opinion while the Sandoval-Barillas scenario is concerned with the distinction between opinion and expert evidence, rendering the opinion evidence as non-expert and inadmissible. The Court of Appeal, by conflating the two issues, seems to suggest a relaxation in the area of opinion evidence that goes beyond the Graat principle.

The difficulties in parsing expert from lay opinion is highlighted in Hachem. ${ }^{43}$ There, the accused was charged with assault-related offences arising from a domestic situation involving his wife and children. The accused allegedly uttered threats in Arabic to his wife. The defence called a witness to translate the utterance and place it in the cultural and linguistic context relative to the accused. The Crown objected to the evidence as lay opinion. ${ }^{44}$ The trial judge found the witness was not an expert, but the evidence was admissible pursuant to the Graat decision. ${ }^{45}$ After hearing the evidence, the trial judge reconsidered his ruling. The Court was "not certain" the evidence was admissible pursuant to Graat, but as it was admitted, the trial judge was "bound" to consider it. ${ }^{46}$ In retrospect, the appropriate approach, as recognized by the trial judge, was to enter into a voir dire on the admissibility of the opinion evidence. ${ }^{47}$ It was especially important, considering opinion evidence is presumptively inadmissible, to determine if it was indeed a compendium of facts and observations as opposed to an opinion offering a conclusion on the ultimate issue of whether the threat fulfilled the elements of the offence. Again, this decision reveals the lack of clarity around the distinction between expert opinion, lay opinion, and observable fact.

Although White Burgess has given us clear direction on expert evidence, Bingley has left us wanting more on the issue of fact as opposed to opinion. Much of the blurring between the two concepts does arise from Graat, which tries to reconcile the reality of witness narrative, where the concept of "just the facts" may render such evidence meaningless, with concerns such evidence may "overwhelm" the trier of fact, resulting in a miscarriage of justice. ${ }^{48}$ Graat and the problems with lay opinion versus expert opinion will be a continuing issue that will require further Supreme Court attention.

Supra note 38 at para 54 .

Supra note 17 at 840 .

Supra note 33 .

Ibid at para 86.

Ibid at para 89.

Ibid.

Ibid.

Supra note 17 at 840 . 


\section{B. SCOPING OUT THE "SCOPE"}

The Sekhon ${ }^{49}$ and White Burgess approach to admissibility of expert evidence involves an initial scope discussion, in which the court marks out the parameters of the proposed expert's evidence. Such scope, once delineated by the court, will be rigidly applied throughout the trial. Should an expert stray outside of the judicially approved scope, the court must reexamine the issue of scope to ensure only evidence that has been filtered through the trial judge's mandate pursuant to White Burgess and Sekhon is admissible. This continuing obligation links scope to the admissibility process and is a recognition of the changing trial landscape that occurs as testimony is given during a trial. Admissibility is no longer a static tool to be applied in a one-time fashion, but is a flexible process responsive to trial needs. Scope is properly a part of that continuing obligation to ensure admissibility is "not conducted in a vacuum."

A strictly adhered-to scope is also connected to the characterization of expert evidence as an exception to the general rule that opinion evidence is inadmissible. ${ }^{51}$ Opinion evidence is presumed inadmissible as it usurps the function of the trier of fact by providing a "readymade inference" on a material fact in issue.$^{52}$ In Sekhon, Justice Moldaver, for the majority, exhorts the trial judge and counsel to be "vigilant in monitoring and enforcing the proper scope of expert evidence. ${ }^{, 53}$ Expert evidence that strays from that judicially authorized scope wanders into opinion territory and is presumptively inadmissible.

Scope issues loom large in case law as they engage and enforce the admissibility and use of expert evidence. Scope is an issue that is not anchored to any particular criteria in the White Burgess framework. Instead, scope is ever-present and functions holistically by transcending any one evidentiary issue. Unsurprisingly, scope issues are sharpened by the blurry edges between observable fact, lay opinion, and admissible expert opinion. Scope requires an expert to stay within her qualified area; but, if such an expert would stray, the trial judge must not only assess the out-of-bounds evidence through the admissibility lens, but must also consider whether the testimony is under the Graat criteria. It becomes evident that the contextual approach created in White Burgess, although all-inclusive, creates a heavily layered approach at trial. With so many moving parts, trial decisions are open to interpretation and appellate review.

R. v. Jacobs ${ }^{54}$ and R. v. Dominic ${ }^{55}$ both Alberta Court of Appeal decisions, highlight the difficulties in manoeuvring through scope issues in circumstances where the expert, as in Sekhon, is a police officer. Both cases involve expert evidence on the consumption patterns of drug users to support a charge of trafficking in drugs rather than personal possession. A police expert gave evidence on an array of information connected to drug culture and usage. The Court in Jacobs identified two ways in which a scope issue may arise. The expert may

Supra note 1. Discussions on scope at paras 46-51.

Abbey, supra note 4 at para 62. Both Sekhon, supra note 1 at para 46, and White Burgess, supra note 2, adopt the comments made in Abbey on the issue of scope.

See Abbey, ibid.

Ibid at para 67; White Burgess, supra note 2 at paras 14-15.

Sekhon, supra note 1 at para 46.

2014 ABCA 172 [Jacobs].

2016 ABCA 114 [Dominic]. 
testify beyond their qualified area, a matter for admissibility, or testify within their area, but without "special knowledge," a matter of weight. ${ }^{56}$ The problem, the Court suggested, is distinguishing between these two issues when the qualified scope is too broadly defined. It appears, in Jacobs, the trial judge committed both errors by relying on evidence outside of the "demonstrated expertise" of the expert and by permitting the officer to testify outside of the scope of the qualified area. ${ }^{57}$ Although Graat is not raised, the issue of testifying inside the expert's qualified area but without expertise suggests an issue earlier discussed in differentiating between observable facts, lay opinion, and expert opinion. In any event, the Court of Appeal found little probative value in the evidence that was in scope and therefore ordered a new trial.

The lesson learned in the Jacobs case is the duty of the trial judge to ensure the scope is circumscribed with "caution and precision" and to read the qualification scope "narrowly and contextually, and in the light of the demonstrated special knowledge" grounding the scope of the expertise.$^{58}$ In the words of the Alberta Court of Appeal, the trial judge has the ultimate duty at all times to "police" the boundaries of an expert's evidence, which "places a high burden" on the trial judge, but is the "unavoidable effect of Sekhon." truly takes on a commiserating tone in instructing the trial judge on this enhanced duty.

The Jacobs decision is applied in the later decision of the Alberta Court of Appeal in Dominic. ${ }^{60}$ In dismissing the appeal, the Alberta Court of Appeal, with a nod to Graat and looking forward to Bingley, clarified that Sekhon "does not undermine the proposition that information gained from others can be used as the foundation for special knowledge." ${ }^{.10} \mathrm{On}$ the scope issue, the Court dismissed the appellant's contention that the evidence given was outside of scope.$^{62}$ In fact, the Court found the expert did stay within scope, albeit the scope was broadly defined. But the Court went even further when they relied on the 1993 Supreme Court decision of R. v. Marquard, suggesting it is "overly technical to reject expert evidence simply because the witness ventures an opinion beyond" the qualified area of expertise. ${ }^{63}$ This comment appears to directly contradict both Sekhon and Jacobs. However, in the Court's view, the expert did have expertise in that further area, and therefore the trial judge properly relied upon the evidence. Perhaps the Court was relying on this outdated case law as a concession to the heavy gatekeeper burden the Supreme Court has placed on the trial judge to be continually vigilant in adhering to the pre-assigned scope.

A clearer decision on an expert testifying outside of qualified scope can be found in $R$. $v$. Threefingers. ${ }^{64}$ The expert was qualified to opine on the "diagnosis, prognosis, and treatment of injuries to human beings," yet the trial judge relied on her evidence on whether those injuries were consistent with consensual sexual activity. ${ }^{65}$ Such evidence was clearly outside of the scope of the area of expertise. This error was magnified by the trial judge's R. $v$. W(D)

Jacobs, supra note 54 at para 52.

Ibid at para 54.

Ibid at para 66.

Ibid at para 65.

Supra note 55.

Ibid at para 32.

Ibid at para 42 .

Ibid, citing [1993] 4 SCR 223 at 244.

2016 ABCA 225 at paras 66-67.

Ibid at para 66 . 
credibility assessment in which he found the expert's opinion in this area as corroborative of the complainant's evidence ${ }^{66}$ As the scope issue was bound up with a $W(D)$ assessment error, the Court found the curative provision could not be applied, and a new trial was ordered. This case is a good example of how scope issues can impact other trial determinations such as credibility assessments. Taking this a little further, in the context of a labour arbitration, an expert's opinion on credibility was ruled "outside the scope of the question he was asked" resulting in the expert taking "on the role of advocate" and lacking the independence required of a duly qualified expert pursuant to White Burgess. ${ }^{67}$ It is not just the content of an expert's testimony that leads to being out of bounds of expertise, but also the tenor of that evidence.

The Alberta courts' approach to the consideration of scope issues is mixed. In some situations, the concern is the undue emphasis that evidence would receive due to the witness' position as an "expert" as seen in Sandoval-Barillas. Other cases emphasize the blurry lines, as suggested in Bingley, between a witness' articulation of their observations "dressed up" to look like opinion and what is really a composite of observable facts. ${ }^{68}$ The inconsistency in the application of scope concerns is a continuing issue despite the clarification from the Supreme Court.

\section{The Two-Step Process}

\section{THE INCEPTION AND COMPOSITION OF THE TWO-STEP PROCESS}

White Burgess, as mentioned earlier, clarifies the approach and framework for admissibility and use of expert evidence. Prior to White Burgess, the 1994 decision of Mohan crafted a number of criteria for admissibility involving relevance, necessity, absence of any exclusionary rule, and a properly qualified expert. ${ }^{69}$ These Mohan criteria became the go-to assessment for expert evidence admissibility and remained intact until the Ontario Court of Appeal decision, authored by Justice Doherty, of Abbey. ${ }^{70}$

It was in Abbey that Justice Doherty attempted to clarify the criteria as explained by Justice Sopinka in Mohan. In Justice Sopinka's view, the relevance criterion was composed of both logical and legal relevance, which included a cost-benefit analysis involving a consideration of the probative value of the evidence. ${ }^{71}$ Relevance, in this interpretation, spoke to reliability and was therefore bound up in a limited weighing of the proffered evidence. ${ }^{72}$ Justice Doherty preferred to separate the cost-benefit analysis from threshold relevance as more properly within the exclusionary discretion or gatekeeper function. He viewed relevancy as purely a threshold issue engaging logical relevance, a common-sense analysis, as opposed to legal relevancy, which advanced a reliability requirement using a cost-benefit

Ibid at para 67, citing $R \vee W(D)$, [1991] 1 SCR 742 [W(D)]

Telecommunications Workers Union, United Steelworkers National Local Union 1944 v Telus Corp, 2016 CanLII 6195 (Alta GAA) at para 78.

See e.g. $R v$ Page, 2017 ABQB 33 at para 25, Renke J.

Supra note 6 at 20.

Supra note 4.

Supra note 6 at 21.

Ibid. 
approach. ${ }^{73}$ To ensure that both meanings of relevancy are situated within their proper context and to make for a more robust assessment, Justice Doherty suggested a two-step approach to admissibility involving the threshold admissibility criteria from Mohan as step one and the gatekeeper cost-benefit analysis as step two. ${ }^{74}$

It is in the discussion of the gatekeeper cost-benefit analysis that Justice Doherty opens the way for the White Burgess decision. In Abbey, Justice Doherty describes the "benefits" analysis as requiring an assessment of the probative value of the evidence. Underlining the probative value is a reliability consideration as "[r]eliability concerns reach not only the subject matter of the evidence, but also the methodology used by the proposed expert in arriving at his or her opinion, the expert's expertise and the extent to which the expert is shown to be impartial and objective." ${ }^{75}$

Here, as taken up later by Justice Cromwell in White Burgess, Justice Doherty is touching on the duty the expert owes to the court as a key aspect of the gatekeeper role. It is that duty and how it should impact expert evidence that is at the core of the White Burgess decision. At issue was whether this "special duty" the expert witness owed to the court to "provide fair, objective and non-partisan" evidence was a matter of admissibility and if so, to which criteria it related. ${ }^{76}$ After commenting on the various case authority approaches to the issue with some courts placing the duty within the relevancy rubric and others in the necessity category, Justice Cromwell, speaking for a unanimous Supreme Court, found the duty required of the expert witness properly resided in both the qualification factor of the Mohan criteria and in the gatekeeper function. ${ }^{77}$

In the second step, the gatekeeper function of the trial judge is engaged as a form of judicial oversight. Although this second step is not novel, arising from Justice Doherty's approach in Abbey, Justice Cromwell, despite his comment in White Burgess that he is adopting the Abbey approach with only "minor adjustments," embeds this gatekeeper function in the grander Supreme Court theme of that time period. ${ }^{78}$ The enhanced gatekeeper function arises in other evidential cases such as in Hart $^{79}$ and Grant ${ }^{80}$ Certainly, White Burgess is using the same analytical framework as espoused in Abbey; nevertheless, Justice Cromwell fills in the framework with a unique discretionary assessment. The trial judge must review the Mohan criteria through the judicial lens of the exclusionary discretion. ${ }^{81}$ This costbenefit analysis requires the judge to "be satisfied that the potential helpfulness of the evidence is not outweighed by the risk of the dangers materializing that are associated with expert evidence." 82 Those dangers, as previously referenced, involve the potential "egregious [miscarriage] of justice" that may arise from an expert who is not independent and

Abbey, supra note 4 at paras $81-84$.

Ibid at paras 76-79, 84-85.

Ibid at para 87.

White Burgess, supra note 2 at para 2.

Ibid at para 10 .

Ibid at para 22.

Hart, supra note 5.

Grant, supra note 5.

White Burgess, supra note 2 at paras $19-20,54$.

Ibid at para 54 . 
impartial. ${ }^{83}$ Justice Cromwell neatly ties the admissibility package in a circular assessment by re-introducing admissibility factors into the cost-benefit consideration.

It is, however, in the detailed analysis of the fourth criterion where the Supreme Court "tightens" and enhances the admissibility approach ${ }^{84}$ In the White Burgess decision, for the expert to be properly qualified, the expert must understand their duty to the court as an independent, objective, unbiased, and impartial witness. Moreover, the proposed expert must show a willingness and ability to fulfill this duty. The threshold is "not particularly onerous," with the Supreme Court in White Burgess suggesting inadmissibility on this basis would "likely be quite rare" and only in "very clear cases." ${ }^{15}$ Notably, however, if a "realistic concern" is raised by the opposing party on the issue, the party offering the evidence must satisfy the trial judge that the expert is in fact objective, independent, unbiased, and impartial. ${ }^{86}$ Additionally, the expert must not be an "advocate" for a party to the action or have any financial or familiar interest in the outcome of the case ${ }^{87}$ Nevertheless, as we will see in the application of this rule, often these considerations become a matter of weight as opposed to admissibility depending on the level of advocacy and interest the expert possesses and the context in which it resides.

White Burgess clearly expands the qualification requirement beyond the previous case authority and trial practice. ${ }^{88}$ Traditionally, the qualification of an expert at trial simply required a recitation of the expert's basis of knowledge and expertise. This usually involved a review of the expert's education and scholarly works and the number of times the witness was qualified in court as an expert. Any other issues involving bias, independence, or partiality were considered weight issues, not admissibility. Admissibility was concerned more with esteem and rank, the trappings and formalities of expertise, rather than with the content and particulars of the witnesses themselves. Yet, the traditional view of what amounts to an expert did not fulfill the core objective of the evidential rules to promote the truth-seeking function of the justice system. Nor did it fulfill the aspirational quality of our evidential rules, which lean heavily on trial fairness as a core value. For partial and biased evidence amounts to non-evidence as it lacks relevancy and materiality to the issues at hand. It can also be viewed as an issue engaging threshold reliability concerns impacting admissibility under the Mohan criteria and the gatekeeper step under White Burgess.

This recalibration of the meaning of qualification sprung up from notable miscarriages of justice resulting from the deferential approach enabled by the traditional qualification exercise. Most significant was the Inquiry into Pediatric Forensic Pathology in Ontario that inquired into wrongful convictions resulting from the biased evidence of a well-known and oft-used pediatric forensic medical "expert," who inaccurately labeled many homicides as "baby-shaking" incidents. The outcome of that Inquiry, the Goudge Report, so named after Justice Goudge who presided over the matter, named the qualification exercise as the responsible factor in the wrongful convictions and recommended the changes as adopted in 
the White Burgess decision. ${ }^{89}$ Although the Goudge Report was released in October 2008, its impact in the courts culminated seven years later in the White Burgess decision. ${ }^{90}$

As early as 9 February 2009, the Ontario trial courts were responding to the Goudge Report and reiterating their gatekeeper function as it relates to admissibility of tainted expert evidence. ${ }^{91}$ However, many of these cases do not clearly differentiate between admissibility and gatekeeper exclusion and tend to emphasize the gatekeeper function as the appropriate step for excluding what would otherwise be admissible expert evidence. ${ }^{92}$ Or, as we will see in Alberta decisions, some courts admit the evidence, but place little weight on it. ${ }^{93}$ Notably, only four Alberta decisions reference the Goudge Report, with one of those decisions postWhite Burgess. ${ }^{94}$ What did change after White Burgess was the recognition that the duty of an expert involving impartiality and independence is clearly an admissibility factor. Although the Goudge Report emphasizes this duty as an important indicator of reliability of the expert testimony, ${ }^{95}$ White Burgess takes it further by embedding the duty directly into the Mohan criteria.

A final consideration in the process is the issue of experts opining in novel areas of expertise. Novelty engages reliability, which was at the core of the earlier-discussed Abbey decision. There, the expert evidence of a social scientist on the meaning of a gang-related tattoo sported by the accused raised reliability concerns at the admissibility and gatekeeper stage. Without diving into the assessment to be undertaken where an expert intends to introduce novel opinion, Abbey set the approach and standard in the area. In many ways this heightened context of novel expert evidence was an incubator for the White Burgess process and colours the White Burgess approach through the scope and duty requirements. Significantly, those concerns transcend the novelty aspect of Abbey in a further indication by the Supreme Court that even previously accepted areas of expertise must be adequately scrutinized to ensure a fair trial and to ensure truth-seeking functions of the court remain intact throughout the trial process.

\section{The White Burgess Two-Step Process IN ALBERTA DECISIONS}

Unsurprisingly, many Alberta cases are driven by the re-interpreted criterion of duly qualified expert. It must be noted that the impact trajectory of White Burgess is "down-up." These concerns arise out of trial decisions and then, through appeals of those decisions, become points of discussion in the Alberta Court of Appeal. Notably, in those early appellate decisions, the Court is wary to accept the White Burgess approach as a substantial ground requiring a new trial. The tendency is to permit a "transitional" period, whereby any

Ontario Ministry of the Attorney General, Inquiry into Pediatric Forensic Pathology in Ontario Report, by the Honourable Stephen T Goudge, vol 3 (Toronto: Queen's Printer for Ontario, 2008) at 487 [Goudge Report] (Justice Goudge raises concerns with admissibility and gatekeeping requirements). There are 90 cases that cite the report as of 7 June 2018. See e.g. JR v University of Calgary, 2012 ABQB 342 at para 206, Read J [JR]; CGL v DKL, 2016 ABQB 71 at para 29, Graesser J [CGL]. The latter decision also applies White Burgess, supra note 2 at para 29.

See e.g. $R$ v Spackman, 2009 CanLII 37918 (Ont Sup Ct J) at 3-4, Trafford J.

Ibid. See also Tavernese v Economical Mutual Insurance, 2009 CanLII 28405 (Ont Sup Ct J) at para 8. SJF v DMK, 2018 ABQB 559 at para 37, Graesser J.

$J R$, supra note 90 at para 206; $R$ v SEL, 2012 ABQB 190 at para 84, Hillier J; $R v$ Laverdiere, 2014 ABQB 161 at para 140, Moreau J; CGL, supra note 90 at para 29.

Supra note 89. 
deviation off the White Burgess track is not considered an error in law. This concession recognizes that many appeals are of trials heard before White Burgess was rendered, but also applies to decisions where White Burgess was clearly applicable, but considered very "new" law. For instance, in one of the first Alberta Court of Appeal decisions rendered after White Burgess, R. v. Alcantara, the Court posited that White Burgess "does not change the relevant law or our conclusion." 96

Another example of the Court of Appeal's slow movement toward White Burgess is in $R$. $v$. Clark. ${ }^{97}$ Identification was in issue at the accused's trial on a robbery charge. The defence introduced the evidence of an expert who was qualified as an experimental forensic psychologist in the "construction and administration of photo lineups." ${ }^{98}$ Although, after a voir dire on the issue, the expert was permitted to testify as an expert, the trial judge ultimately found the expert's evidence was not admissible at trial as it was not necessary to assist the trier of fact. The evidence did not fulfill the necessity requirement under the Mohan factors as the evidence was "clearly within the knowledge of judges and properly instructed jurors." 99 This approach to the admissibility of the expert evidence at trial was based on the traditional view, before White Burgess, that qualification was based on education and expertise. Continuing in this "old school" vein, the Alberta Court of Appeal referred only to the Abbey decision even though Sekhon and White Burgess had been released at the time of the appeal.

As previously conjectured, 2015 and 2016 decisions from the Court of Appeal considered trials conducted in the transition period of White Burgess and may be more apt to make concessions to the trial judge's approach as a result. ${ }^{100}$ A good example of this approach is found in the 2016 decision of R. v. Soni. ${ }^{101}$ In that decision, the majority commented on trial counsel's knowledge that White Burgess was under appeal. In their view, White Burgess did not "change" the law, but built upon the principles already found in earlier case law. In fact, trial counsel was aware that qualification issues went to admissibility, not just weight, when the issue was conceded at trial. ${ }^{102}$ The Court went even further to find that:

White Burgess does not compel a trial judge to perform any independent analysis about the admissibility of expert evidence when the parties concede that it is admissible. The trial judge likely has an overriding ability to exclude the evidence notwithstanding the admission, but failing to do so or to perform the analysis is not an error. The resulting concession by counsel that the expert evidence was admissible should prevail on appeal. $^{103}$

This position is not entirely accurate considering the vigilance required of the trial judge, per Sekhon, in "monitoring and enforcing the proper scope of [the experts'] evidence."104 Although this quote presumes admissibility, it highlights the importance placed on the expert

2015 ABCA 259 at para 175, leave to appeal to SCC refused, 36732 (18 February 2016). 2016 ABCA 72 [Clark].

Ibid at para 38 .

Ibid at para 66.

See $R$ V Soni, 2016 ABCA 231 [Soni]; $R \vee$ Apetrea, 2016 ABCA 395 at para 12 [Apetrea]; $R v$ Balla, 2016 ABCA 212 at paras 54-55 [Balla].

Soni, ibid.

Ibid at paras $15-16$.

Ibid at para 16 [emphasis in original].

Supra note 1 at para 46. 
providing admissible evidence. This should suggest that even more vigilance is required when it comes to the issue of whether an expert's evidence is admissible ab initio. Moreover, as it is clear in White Burgess, the exclusionary discretion consideration found in the second step of the admissibility assessment is not itself discretionary. That crucial second look at the evidence may make all the difference between a fair trial and one that results in a miscarriage of justice.

The majority of the Court in Soni found the trial judge took into account the diminished weight of the expert evidence in her final assessment, and therefore a new trial was not warranted. The Court found " $[\mathrm{t}]$ here is nothing on this record to suggest that the expert's objectivity was so lacking that his evidence should have been ruled completely inadmissible." "105 Yet, on a plain reading of White Burgess, the evidence on objectivity should have raised a "realistic concern" requiring a further assessment. Although the threshold is low in considering qualifications, the Court's position that the expert's objectivity needed to be lacking before admissibility was a viable issue is placing the threshold too low. In any event, the Court applied the proviso and found there was "ample other evidence" supporting the conviction. ${ }^{106}$ Most likely it was this last factor that impacted the dismissal of the appeal. Indeed, Justice Berger's concurring decision takes the preferred approach by finding the trial judge did not correctly apply White Burgess as required and that the appellate court, left with the trial judge's finding that the expert "lacked the objectivity and impartiality expected of an expert witness," should have found the evidence inadmissible. ${ }^{107}$ Justice Berger then correctly applied the proviso by finding there was sufficient evidence to warrant a conviction.

In Dominic, another 2016 transitional judgment, the Court of Appeal appears to dismiss the appellant's contention that evidence outside of scope must be excluded, clearly contrary to White Burgess, Sekhon, and Bingley. ${ }^{108}$ Although scope of the evidence was not the primary issue in White Burgess, the decision highlights the vital importance of "strictly" adhering to the regime to ensure a fair trial and protection against miscarriages of justice. Bingley emphasizes the containment of the scope through vigilance of counsel and the court and, where scope strays, the possible requirement of entering into a further Mohan inquiry.

This cursory approach to the White Burgess ideals is also found in the 2016 Balla decision, in which the Court of Appeal dismissed an argument that the trial judge failed to apply the gatekeeper step. In the Court's view, the expert only "mildly" strayed from the scope of their qualified evidence. ${ }^{109}$ In that case, the evidence went in without objection in a pre-White Burgess, although post-Sekhon, decision. The Court dismissed the ground by applying the "no substantial wrong" proviso. ${ }^{110}$

The lower courts too struggle with the application of the newly refined "duly qualified expert" in White Burgess. On the civil side, direct financial interest is a basis for exclusion. ${ }^{111}$

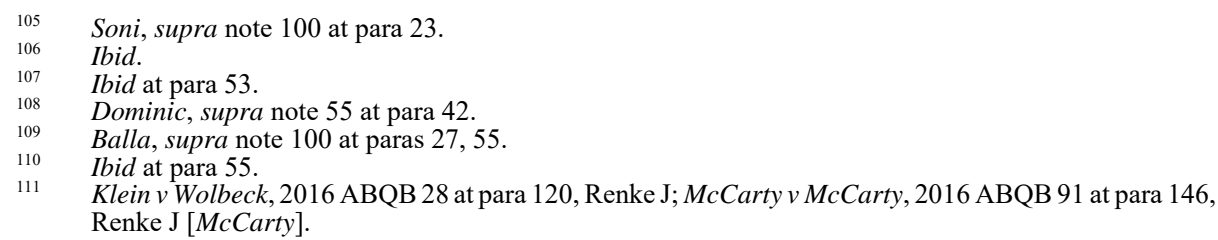


Conversely, financial interest through employment does not tend to render the expert's evidence inadmissible. ${ }^{112}$ Even an expert, who has been employed by a third-party defendant to the action, is qualified to testify. ${ }^{113}$ Consistent with this view, the mere fact that a use of force report was written by a former police officer is not enough to "give rise to a concern regarding the objectivity of his opinion." ${ }^{\prime 14}$ However, in R. v. Page, a 2017 trial decision of Justice Renke, the expert was a police officer providing evidence on the issue of personal drug use versus commercial trafficking. ${ }^{115}$ The Court correctly determined that the connection raises realistic concerns on the qualification issue. After a survey of the factors that would impact independence, objectivity, and impartiality, Justice Renke found it was not a clear case requiring exclusion. There is no clear indication in that decision how Justice Renke approached the gatekeeper step in his analysis.

The lower court decisions do recognize the concept that the expert is "less a "witness for a party' than a 'witness for the court." 116 This "neutrality principle" is explored in Morrill and is connected to the concern with the expert as advocate. ${ }^{117}$ In Morrill, Justice Erb listed factors to consider in the admissibility of expert evidence as per the earlier decision of Lindsay as follows:

(i) An expert should provide independent assistance to the court and the parties by way of objective unbiased opinion in relation to matters within the expert's expertise. The expert witness should never assume the role of an advocate.

(ii) The expert evidence should be and be seen to be, the independent product of the expert uninfluenced as to form or content by the exigencies of the litigation; and

(iii) An expert should be ready to reconsider the opinion given and if appropriate to change the opinion upon receipt of new information or upon consideration of the opinion of other experts. ${ }^{118}$

In Morrill, the three experts were called to testify on a determination of mental disorder coupled with possible intoxication. After articulating the factors on admissibility of expert evidence, Justice Erb meticulously applied them to each expert's evidence. In doing so, the Court noted considerable problems with one expert's evidence, which did not result in a finding of admissibility, but a lack of weight. Morrill, a 2016 decision, is another example of the trial courts applying White Burgess in spirit, but when real issues of admissibility under that new regime are apparent, preferring to approach the issue with caution by admitting the evidence and then placing little to no weight on it in the final analysis. ${ }^{119}$

Geophysical Service Incorporated v Encana Corporation, 2016 ABQB 230, Eidsvik J. Brookfield Residential (Alberta) LP (Carma Developers LP) v Imperial Oil Limited, 2017 ABQB 218 at para 62 , Graesser J [Brookfield].

114 Heffernan v Alberta, 2018 ABQB 13 at para 74, Henderson J; Soni, supra note 100 at paras 19, 32.

1152017 ABQB 33, Renke J.

$116 \quad R$ v Lindsay, $2016 \mathrm{ABQB} 251$ at para 122 [Lindsay], citing 1159465 Alberta Ltd $v$ Adwood Manufacturing Ltd, $2010 \mathrm{ABQB} 133$ at para 2.13; $R$ v Morrill, $2016 \mathrm{ABQB} 638$ at para 82, Erb J [Morrill].

Morrill, ibid.

Ibid at para 83.

Ibid. See also CGL, supra note 90 at paras 28-30; LAU v IBU, 2016 ABQB 74, Michalyshyn J [LAU]; East Winds Caribbean Limited Partnership v Reti, 2016 ABQB 536 at para 52 [East Winds] (Master Hanebury did not admit the evidence). 
The meaning of advocacy appears to be contextual as in Kitching $v$. Devlin, a case involving a professional negligence action against a lawyer. ${ }^{120}$ Both parties to the action called lawyers as experts who "advocated" for their "respective independent opinions."121 This, however, did not make their evidence inadmissible as neither expert did so at the behest of their retainer. As part of the expert-as-advocate concerns, the courts are sensitive to experts who are unable to fulfil their duty to the court as independent and impartial experts. This is particularly the case with opposing experts who are too "competitive and eager to engage both one another and opposing counsel" as in Baker v. Poucette. ${ }^{122}$ The "extremely argumentative" expert's report was deemed inadmissible by Justice Neufeld as a result, even though "[r]ebuttal (and surrebuttal) reports are inherently adversarial and a certain amount of latitude can be afforded." 123

Sometimes the concern that the expert may not "meet their duty to the Court of being fair, objective and non-partisan" arises from an array of factors. ${ }^{124}$ In Burby, where capacity was in issue, Justice Tilleman noted the expert evidence on decisional capacity, which came from both parties to the action, was helpful, but the reports they proffered on retrospective capacity were of "questionable" value as they were "not subject to the rigours of evidence testing at trial." $" 125$ The opinions in the reports were based on the foundational facts received by the parties, often hearsay and double hearsay, and therefore favoured the side for which the report was prepared. ${ }^{126}$ Reliability of both the information given to the experts and the methodology employed in the novel area of retrospective competency resulted in Justice Tilleman "not accepting one of the expert reports over the other." 127 As a result, Justice Tilleman came to his own conclusions, based on all of the evidence, on the issue. ${ }^{128}$

By 2018, it appears that the trial courts are meticulous in their review of the experts' duty to the court, such as in R. v. Longridge. ${ }^{129}$ In that decision, Justice Renke reviews and considers the evidence on each of the three White Burgess issues of impartiality, independence, and bias in deciding to admit the experts' evidence. ${ }^{130}$ The experts were deemed independent in two senses: in the sense "that each opinion was the product of independent judgment, and in the sense that neither was influenced by the interests of the party calling him or the outcome of the litigation." 131 On impartiality, the Court considered whether the experts were advocates. ${ }^{132}$ The experts were not biased as they both gave "dispassionate and objective assessments of the evidence and duly considered evidence that could support inferences contrary to their conclusions." 133 Finally, Justice Renke designated both experts as neutral "friends of the court." ${ }^{134}$ Consistent with the constant blurring of lines between the Mohan factors in White Burgess, the neutrality of the experts was founded on

2016 ABQB 212.

Ibid at para 152 .

2016 ABQB 557 at para 153, Neufeld J.

Ibid at para 154 .

Burby v Ball, 2017 ABQB 300 at para 174, Tilleman J [Burby], aff'd 2018 ABCA 22.

Burby, ibid at para 175 .

Ibid at paras $172-73$.

Ibid at para 178 .

Ibid at para 177 .

2018 ABQB 145, Renke J [Longridge].

Ibid at paras 18-22.

Ibid at para 19.

Ibid at para 20.

Ibid at para 21.

Ibid at para 22. 
their ability to offer "reliable and highly probative evidence." ${ }^{135}$ Reminiscent of the approach delineated by Justice Erb in Morrill, this 2018 decision shows a sophisticated and thoughtful approach to this value-laden assessment, crucial to the fair trial concerns in White Burgess.

Burby is also a good example of the subtleties of expert evidence, portions of which may fulfill the White Burgess regime and portions of which do not. Reliability may be an issue bound up in the duly qualified expert criterion as well. This, as discussed earlier in this article, was certainly the situation facing the Supreme Court in White Burgess. Again, this decision highlights the blurred lines between admissibility and weight. In Burby, Justice Tilleman did not explicitly find the reports inadmissible even though he did not rely on them.

Reliability and novel science, as separate concerns, also engage the trial courts in applying the expert evidence regime. As mentioned earlier, the placement of reliability in that regime was arguable until the Ontario Court of Appeal's decision in Abbey. White Burgess adopted the Abbey approach, and yet threshold reliability as opposed to gatekeeper reliability as opposed to ultimate weight reliability still remains a point of contention in the application of White Burgess. Often the lines drawn between these steps are unclear, and the result is an unequal treatment of reliability in the trial courts. Burby gives one such indistinct example of application of reliability issues at trial. In another example involving appellate review, the Alberta Court of Appeal in Sandoval-Barillas found the novel expert evidence was simply "unnecessary and inadmissible" per the Mohan criteria. ${ }^{136}$ The Court there did not even engage in a White Burgess discussion.

Similarly, R. v. Awer, a decision of the Alberta Court of Appeal upholding a sexual assault conviction, ultimately reversed by a majority of the Supreme Court in 2018, turned on the reliability concerns of opposing defence and Crown experts. ${ }^{137}$ Specifically, the defence DNA expert impugned the reliability of the Crown's DNA expert, suggesting the evidence was speculative and without scientific foundation. Justice Moldaver, in the brief majority decision, did not decide on the admissibility of the Crown's expert evidence, but he did observe a failure by the trial court to fully consider the import of reliability in novel expert evidence. In Justice Moldaver's opinion, a voir dire on the issue of the sufficient reliability of the evidence may be required at a new trial. This suggestion is certainly consistent with White Burgess, Bingley, and Abbey. Awer is an example where the appellate court was fully cognizant of the principles flowing from White Burgess and Sekhon and their impact on the fifth Mohan criterion of novel science yet erred in its application of those principles. ${ }^{138}$

One of the more recent decisions engaging expert evidence issues, $R$. v. Stephan, is yet another Alberta appellate court decision overturned by the Supreme Court on the use of extensive expert evidence at trial. ${ }^{139}$ Although the Court of Appeal decision was not exclusively focused on expert evidence, it is the expert evidence issues that ultimately matter. The Supreme Court overturned the conviction on the basis of the dissent of Justice O'Ferrall, which found error in the trial judge's conflation of the actus reus and mens rea requirements

Ibid.

Supra note 38 at para 62 .

2016 ABCA 128 [Awer CA], rev'd 2017 SCC 2 [Awer SCC].

Awer SCC, ibid at para 3; Awer CA, ibid at paras 28-49.

2018 SCC 21, rev'g 2017 ABCA 380 [Stephan]. 
under section 215 of the Criminal Code ${ }^{140}$ However, the essence of the error was the Crown's evidence relating to those concepts, which was given almost exclusively by experts, and the inability of the defence to lead lay expert evidence.

Stephan is a further instance of how expert evidence issues are not self-contained and can taint the entire viability of a case. Issues of opinion evidence, admissibility, necessity of expert evidence, scope limitations, and duly qualified experts are exacerbated by proper application of offence requirements, the sufficiency of jury instructions, and the proper burden of proof. Stephan underlines the difficulties encountered when expert evidence lies factually at the heart of the case. It is also a reminder of the primary purpose of the White Burgess regime as a response to the potential miscarriage of justice should expert evidence be wielded in a desultory fashion.

Finally, there does not appear to be a great inclination to gate-keep in keeping with the second step of White Burgess (this is the difficulty of the courts properly engaging their gatekeeper function under the second step as envisioned by White Burgess). The Dominic decision provides an example of where the appellate court fails to appreciate that the gatekeeping second step requires a further, not first, look at the Mohan criteria through the specially enhanced lens of judicial oversight. ${ }^{141}$ However, over time, as the courts manage the implications of White Burgess, a deeper understanding will emerge, resulting in a more nuanced articulation and application of the approach. White Burgess becomes a symbol of the general importance of the trial as a gatekeeper who is obliged "to ensure that evidence allowed into trials is relevant and does not invite improper reasoning."

\section{Weight MatTers!}

The expert's relationship to their duty to the court also informs both admissibility and weight. Staying within the role of an expert, not just staying within the scope of that expert's evidence, is viewed in White Burgess as a continual obligation of the trial judge to enforce as gatekeeper throughout the course of the trial, which does not end when the gatekeeper becomes the decision-maker. The twin concerns of duty and scope are clearly connected to the ultimate weight to be placed on the evidence. In that final assessment, all aspects of the probative value of the evidence is weighed together with the whole of the evidence. At this stage, in which the court applies the ultimate burden of proof to the entire trial evidence, expert evidence dissolves into one of many considerations leading to the final decision. The importance of maintaining at the forefront the various concerns emanating from the admissibility of expert evidence as identified through White Burgess is reflected in the admonishment by the Supreme Court to consider all potential expert evidence frailties through to the end. In many ways, White Burgess creates a three-step process: admissibility, exclusionary discretion, and ultimate weighing. All three steps are distinctively separated from each other in White Burgess, but whether the lower courts are able to hold onto those distinctions during implementation is a point of discussion.

\footnotetext{
140 RSC 1985, c C-46.

141 White Burgess, supra note 2 at paras 23-24.

$142 \quad R v$ Barton, 2017 ABCA 216 at $\mathrm{n} 46$.
} 
Earlier, I referenced several cases where the Alberta courts admitted expert evidence despite independence, partiality, and advocacy concerns. ${ }^{143}$ In accordance with White Burgess, although the evidence was admitted, the Courts, in assessing the evidence through the White Burgess lens, gave the evidence little to no weight. In two cases, the Court admitted the evidence, but, for reasons of a lack of probative value, placed no weight on the opinions. ${ }^{144}$ In Brookfield, the opinion was "merely speculation supported by virtually no evidence,"145 and in McCarty, the opinion amounted to "a mere or bare assertion."146 Although this treatment by the Court indicates a clear understanding of the White Burgess regime in separating admissibility from weight, it also shows a reluctance to find such expert evidence inadmissible based on the Mohan criterion of relevancy or even to consider whether the evidence would assist the Court. Of course, relevancy is often unclear until the evidence is heard; however, it should also not be forgotten that it is a legitimate area of investigation under a Mohan voir dire.

The difficulties of applying White Burgess in the realms of admissibility and weight are highlighted in McKinlay v. Zachow, where Justice Yungwirth scrupulously applies the White Burgess regime. ${ }^{147}$ Here, the expert evidence was admissible, but only for a limited purpose. ${ }^{148}$ The scope issue appears to have been determined on concerns of objectivity and lack of clarity around the proposed evidence. ${ }^{149}$ This suggests, as required by White Burgess, that scope, objectivity, and reliability are overarching issues that defy boundaries. In many ways, White Burgess requires courts to conflate admissibility with ultimate weight.

\section{E. THEMES OF INNOVATION ARISING FROM Current Alberta Case Developments}

This section will identify various themes arising from the case law suggestive of future trends and legal issues arising from the application of White Burgess in the Alberta courts. These themes of innovation not only impact expert evidence principles, but also other related areas such as opinion evidence, threshold reliability, proof issues, and technological advances. The impact possibilities of expert evidence are potentially endless as the courts find further connections between the treatment of expert evidence and other evidential areas. The following nine areas of impact must thus be seen as a continuing dialogue with the courts as law is created through the White Burgess principles.

The first innovation can be found in the overarching complexity of the decisions in which issues of scope, admissibility, independence, and weight regularly arise. Overlaid on this complexity is the intersection of grid-like evidentiary rules involving the ultimate issue rule, hearsay rules, the opinion evidence rule, and the judicial exclusionary discretion. It is in this expert evidence landscape where we truly appreciate the need for a three-dimensional perspective to thoroughly understand the inner workings of evidentiary rules.

\footnotetext{
143 CGL, supra note 90 at paras 28, 30; LAU, supra note 119; East Winds, supra note 119

144 Brookfield, supra note 113; McCarty, supra note 111.

145 Brookfield, ibid at para 63.

146 Supra note 111 at para 146.

1472018 ABQB 365 at paras 100-104, Yungwirth J.

$148 \quad$ Ibid at para 104.

$149 \quad$ Ibid at para 105.
} 
In the second theme, as touched upon above, the new regime impacts the principles of opinion evidence. As the expert evidence rule is an exception to the general rule that opinion evidence is inadmissible, the sub-issue of whether the evidence is in fact expert or lay opinion often arises in trial decisions. These decisions give a strong indication that Graattype evidence is still very much a viable concern under the White Burgess regime. The influence of Sekhon may be at work here too. For instance, in Dominic, the Alberta Court of Appeal did suggest that "Sekhon does not undermine the proposition that information gained from others can be used as the foundation for special knowledge." ${ }^{\prime 50}$ Of note, is the Court's view that the "impugned evidence cannot be considered in isolation," but must be considered in the "context" of the totality of the expert's evidence. ${ }^{151}$ This suggests a broad and purposive approach to the evidence. As also observed in the Sandoval-Barillas decision, the Alberta Court of Appeal may be signaling a broader approach to opinion evidence, relaxing the traditional presumption against inadmissibility of such evidence and blurring the lines between what is considered expert evidence and what is considered lay opinion evidence.

The third innovation arises from the courts' movement toward an openness in considering necessity as an ultimate proof issue. Whether evidence is necessary is the long-applied criterion from Mohan, but in Justice Gate's decision in R. v. TWS, necessity, novel science, and proof requirements are intertwined. ${ }^{152}$ In that case, Justice Gates considered the admissibility of expert evidence on the frailty of a child's memory to assist the jury in determining credibility and reliability. Of note, TWS was a jury trial, and therefore the necessity requirement differed from a trial judge sitting without a jury. A trial judge, as trier of fact, would have the benefit of judicial insight and expertise in assessing credibility and reliability, while a jury would not have those inherent skill sets. In admitting this type of expert evidence, anchored in the White Burgess approach, the innovation power of the new regime is clear.

Although not as robust an example, in R. v. Greenley, Judge Allen also considered the need for expert evidence on the Crown witness' ADHD diagnosis. ${ }^{153}$ The trial judge speculated that such expert evidence, based on the factors to be considered in White Burgess, "might" have been admissible, but there was no requirement that the Crown call such evidence. ${ }^{154}$ Again, the possibilities of what constitutes an expert is wide open under White Burgess, but such finding of expertise does not relieve the court and counsel from their heavy responsibility to ensure a fair trial. Thus, scope and gatekeeper vigilance is required. Any significant deviation from this rigid regime could result in a miscarriage of justice resulting in a new trial upon appeal.

Consistent with the opening up of necessity is the new regime's significantly different conception of impartiality, independence, and objectivity as an integral part of the qualification of the expert. This enhanced qualification criterion is the fourth innovation flowing from White Burgess. When previously qualification only meant the expert must have the education, expertise, and weight of authority expected from an expert in the field, White

$\begin{array}{ll}150 & \text { Supra note } 55 \text { at para } 32 . \\ 151 & \text { Ibid at para } 35 . \\ 152 & \text { 2018 ABQB 282 [TWS]. } \\ 153 & \text { 2017 ABPC 148 at para } 130 . \\ 154 & \text { Ibid at para } 132 .\end{array}$


Burgess enhances that meaning to include a broad view of an expert as a "friend" of the court. Even though the courts in applying this requirement emphasize the low threshold for qualification, this new approach necessitates a discussion on the issue of bias, which must be apprised in the final weight to be given to the evidence on the ultimate issue. Truly, the qualification framework acts as another oversight mechanism and is the true legacy of White Burgess.

Alberta courts have taken this enhancement of the qualification exercise seriously. This is explicitly seen in R. v. Morrill in which Justice Erb lists factors to consider in the admissibility of expert evidence, as discussed earlier in this article. ${ }^{155}$ Although the application of these factors are less than satisfactory considering the findings, the list indicates an innovation arising from White Burgess. Of interest is the last factor that an expert should be "ready to reconsider" their opinion depending on the circumstances. ${ }^{156}$ This factor, as a dimension of neutrality, is not explicitly voiced in White Burgess, but easily flows from that decision. This is an example of the innovation found in the trial courts in this area of White Burgess. Morrill is an early decision from 2016, and the expectation would be that in 2018, if applied properly, such factors could be used robustly in such a manner that would fulfill the spirit of White Burgess.

Further extension, and therefore the fourth innovation, flowing from this impartiality concept can be found in the application of White Burgess to court-appointed experts under the civil Rules of Court. ${ }^{157}$ In Prediger v. Santoro, the Alberta Court of Appeal found a courtappointed expert should still be evaluated under the White Burgess regime, but with modifications. ${ }^{158}$ Such an expert would not, according to the Court, raise concerns of independence or bias as would an expert retained by a party to the case. The concept of the expert as impartial, independent, and unbiased has also impacted liability and professional negligence. In Arndt v. Banerji, the majority faced a collateral attack on the expert opinion in a WCB claim. ${ }^{159}$ The majority reiterated the White Burgess regime indicating bias, impartiality, and lack of independence was a matter for admissibility, but once admissible, "the expert cannot be sued on the basis that the opinion was 'incorrect' or even 'negligent'.,"160

The fifth innovation revolves around the final assessment of expert evidence. In the final analysis, such evidence, as with all evidence, is subject to a credibility determination and must be assessed in the context of the criminal burden and standard of proof. Of interest in Awer is the Supreme Court's reason for quashing the conviction and ordering a new trial, based on the ultimate weight apportioned to the expert evidence and the application of the burden of proof to it. In Awer, the trial judge erred by accepting the Crown's expert evidence while subjecting the defence expert's evidence to "intense scrutiny."161 These "materially different levels of scrutiny" effectively reversed the burden of proof onto the accused. ${ }^{162}$ This 
is an indication that expert evidence issues will continue to engage matters relating to the ultimate weight to be given both through the new approach of White Burgess and the wellknown $W(D)$ principles. ${ }^{163}$

The sixth area of innovation moves the thematic lens from the evidence itself and toward appellate review of findings based on that evidence. The Alberta Court of Appeal tends to prefer a broad, contextual approach in their appellate review of the issue. ${ }^{164}$ This is consistent with the Court's deference to the trial judge, particularly considering the overlay of judicial discretion under the second step. However, the complexity of expert evidence as a mixer of law and fact engages differing, and therefore difficult-to-apply, standards of review. Expert evidence, as a legal test, must be reviewed on the standard of correctness as a question of law. However, the qualification of the expert and the probative value of the evidence requires deference to the trial judge as a factual consideration, ${ }^{165}$ although this position should be approached with caution as the Supreme Court case cited as support for it was decided in the context of an administrative tribunal under specific statutory authority. The Alberta Court of Appeal has properly found that no deference is given where the trial judge failed to "undertake their gatekeeping function."."166

The seventh area of impact of these decisions is on other evidentiary principles. For instance, there is potential impact on the evidential rules relating to reliability. Reliability, as a continuing factor in the gatekeeper function, is given increasingly heightened importance in evidentiary principles. ${ }^{167}$ Here, too, issues of threshold reliability and weight reliability are raised. For instance, the Clark decision may raise special concerns on the appropriate standard for the admissibility of defence-led expert evidence in the gatekeeper portion of the test through the application of Grant. ${ }^{168}$ This would be of particular concern where the expert evidence lends support to an argument that a third party, known or unknown, committed the offence. It could be argued that, in applying the Grant decision, the court must consider, if the expert is proffered by the defence, whether the prejudicial effects of admitting the evidence is substantially outweighed by the probative value of the evidence. Indeed, in Grant, the evidence that a third party was responsible for the offence was connected to the DNA defence expert's evidence. This argument was raised in the British Columbia Court of Appeal decision of R. v. Wiens, with the Court declining to decide that issue based on the facts of the case before them. ${ }^{169}$ Certainly, it could be argued that in the case, the evidence was directly connected to identification, which raised the possibility that an unknown third party committed the offence. For further discussion, see Sandoval-Barillas, another Alberta Court of Appeal decision on the issue. ${ }^{170}$

Finally, these cases give us a sense of the future implications of this area of the law. The notable area of impact will be on the admission and use of digital evidence, a challenging, new area of jurisprudence for the courts. Expert evidence is neatly tied to the use of

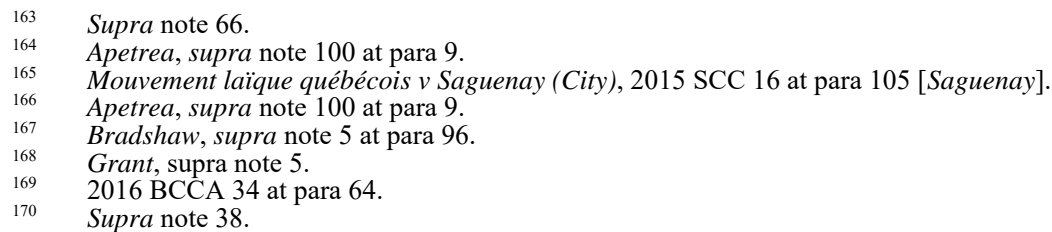


technology in the courtroom, such as PowerPoint presentations. Notable is the Kon decision in which the Alberta Court of Appeal discusses the intersection of opinion evidence and technology in relation to the admission of an electronic record. ${ }^{171}$ Difficulties in approaching this type of evidence abound. Digital evidence does not fit neatly into the traditional modes of evidentiary admissibility as it is neither wholly documentary nor wholly parole-type evidence. As such, it is also an unknown quantity with a mystique. Although some courts are taking judicial notice of the workings of some sources of digital evidence such as Facebook, other social media platforms and applications require expert evidence to elucidate the court on the inner workings of these evidentiary mechanisms. To then enfold into the mix the concept that the evidence in and of itself may be opinion evidence is even more daunting.

This final theme, engaging the future of what we, in law, label as evidence, is an area with deep ramifications as more and more of our daily routines are digitized. In Kon, the Court considered the possibility that such digital evidence may become opinion if it is "sufficiently idiosyncratic, sophisticated, and judgmental" and thus becomes a matter of "specialized knowledge" or even "novel or contested science." ${ }^{172}$ Conversely, such evidence may be a "manifestation of ordinary learning" and not take on the expert evidence dimension. ${ }^{173}$ This decision is a good reminder to the trial courts to be mindful of the evidence before them in whatever form it takes. It is also a strong indicator that expert evidence, in its enhanced format, will influence innovations in our laws.

\section{The InfluenCe FaCtor}

The influence factor will attempt to measure the impact of the White Burgess regime by looking at the implementation and usage of that new approach. The Supreme Court, as the court of final appeal, has the potential to either change or uphold legal principle. There is a broad range of change from overruling a legal principle to distinguishing it. ${ }^{174}$ Change can create new rules, such as in Hart with the creation of a new common law rule to deal with Mr. Big confessions. ${ }^{175}$ Change can also build upon traditional legal principles, updating them to reflect current legal practices or current legal issues. White Burgess is an example of this kind of "tweaking" or updating of a legal principle by a court.

In White Burgess, we see the Supreme Court retain continuity from traditional Wigmore concepts as used in the 1990 Mohan criteria, but then enhance that tradition for a welldefined purpose - a purpose that is a twenty-first century concern with the integrity of the justice system yet that is very much tied to the traditional precepts of our laws of evidence: the truth-seeking function of the courts. The reason for this change is clearly enunciated in the first line of White Burgess in which Justice Cromwell, speaking on behalf of the sevenmember panel, explains that "[e]xpert opinion evidence can be a key element in the search for truth, but it may also pose special dangers." ${ }^{176}$ Justice Cromwell pinpoints the special dangers as an expert whose "lack of independence and impartiality can result in egregious

\footnotetext{
$171 \quad$ Supra note 28.

172 Ibid at paras 21-24.

173 Ibid at para 25

174 Daved Muttart, The Empirical Gap in Jurisprudence: A Comprehensive Study of the Supreme Court of Canada (Toronto: University of Toronto Press, 2007).

175 Supra note 5.

176 Supra note 2 at para 1.
} 
miscarriages of justice." ${ }^{177}$ Truth seeking is inextricably entwined with fair trial concerns: false evidence impedes the truth-seeking function, negatively impacts the integrity of the justice system, and thereby corrodes public confidence. At the heart of White Burgess is not just the search for truth, but just and fair determinations.

Contextually, the Canadian justice system has experienced specific instances of such miscarriages as exemplified in the Goudge Report, where the admission of the flawed evidence of one expert resulted in dozens of wrongful convictions. ${ }^{178}$ The first mention of the Goudge Report in the Supreme Court connected to the vagaries of expert evidence was in the 2013 Canada (Attorney General) v. Bedford decision. ${ }^{179}$ In that case, in finding deference is owed to the trial judge in their determination of social and legislative facts on a Charter application, Chief Justice McLachlin referenced the Goudge Report on the trial judge's role as it relates to social science evidence from an expert witness. In the Supreme Court's view, "[t]he assessment of expert evidence relies heavily on the trial judge ... particularly so in the wake of the Ontario report by Justice Goudge, which emphasized the role of the trial judge in preventing miscarriages of justice flowing from flawed expert evidence." 180 White Burgess cited the Goudge Report, together with earlier similar inquiries, for the "critical need for impartial and independent expert evidence in civil litigation." 181 Notable is the emphasis on civil litigation encompassing the entire justice system, not just the criminal.

Even before the release of White Burgess ${ }^{182}$ on 30 April 2015 and Sekhon ${ }^{183}$ on 20 February 2014, the Supreme Court was concerned with reliability and assessing the probative value of expert evidence. ${ }^{184}$ In Saguenay, ${ }^{185}$ a case applied in White Burgess ${ }^{186}$ and released two weeks before, ${ }^{187}$ the Supreme Court suggested it was "well established that an expert's opinion must be independent, impartial and objective." 188 However, Justice Gascon was primarily concerned with deference to the tribunal's decision-making on the use of expert evidence in the administrative context. Although, as mentioned, the Supreme Court in White Burgess quotes Saguenay and applies it, Justice Gascon in Saguenay, contrary to White Burgess, suggests that a lack of those factors neither disqualifies an expert nor does it "always" amount to "insurmountable barriers" to admissibility of the evidence. ${ }^{189}$ Although Justice Cromwell in White Burgess requires a realistic concern be raised on such issues before admissibility is in question, this is only after the expert indicates in their testimony that they are impartial, unbiased, and independent and understand their duty to the court. Further, the Supreme Court in White Burgess views a qualified expert as one with these characteristics and does not, as it seems in Saguenay, require two separate assessments. Even with the release of White Burgess, the Supreme Court did not readily apply the decision. Still

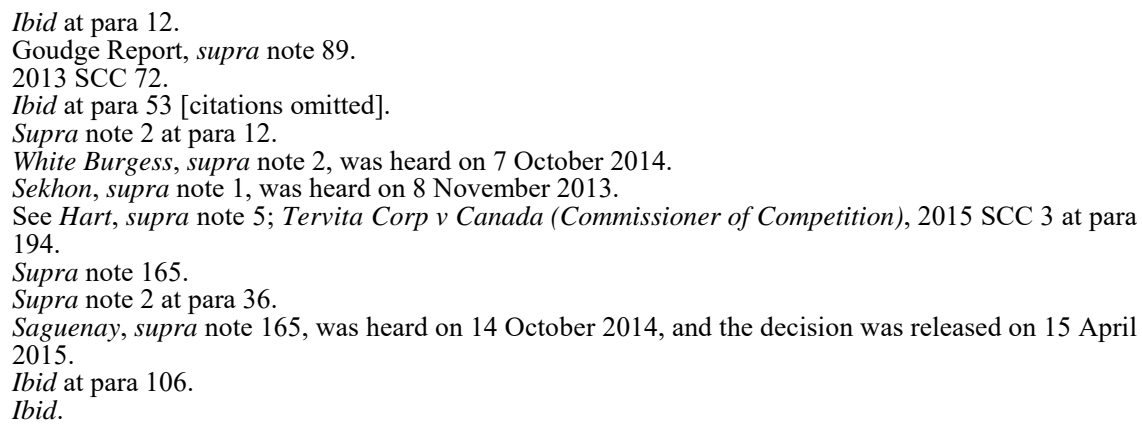


there have been Supreme Court decisions on expert evidence, such as Benhaim v. St-Germain. ${ }^{190}$ In fact, in the body of Supreme Court case law, White Burgess is only cited in the Bingley case. Even Abbey has been applied more often. ${ }^{191}$ Even so, White Burgess, as a unanimous decision, serves to underline the importance of scrutinizing expert evidence with care. A change in legal principle is not done in a vacuum.

In order to determine the impact of the new approach to expert evidence, a database search was done to determine the citation power of the new case law. Considering White Burgess is the judgment outlining a new regime for admissibility and use of expert evidence, this decision should be at the heart of all expert evidence cases. As discussed earlier in this article, although White Burgess builds on the previous law invoking the Wigmore or Mohan criteria for admissibility of expert evidence, it embellishes the criteria and significantly builds on it. After White Burgess, no court grappling with expert evidence should be relying on the Mohan test alone. As of 16 September 2018, 47 Alberta cases cite the White Burgess decision. ${ }^{192}$ The cases are virtually equally split between criminal, regulatory, and civil. ${ }^{193}$ In the criminal law field, there are a variety of offences, such as second-degree murder charges in Longridge $e^{194}$ and Iyamuremye $e^{195}$ and motor vehicle and dangerous driving charges in $R$. v. Paquette. ${ }^{196}$

In the arena of expert evidence, it is not the charge that matters, but the purpose of the expert evidence in any particular case. For instance, Paquette and Longridge use expert evidence to form the foundation for mental disorder under section 16 of the Criminal Code. They are also both decisions rendered by Justice Renke of the Alberta Court of Queen's Bench. In fact, Justice Renke is the author of nine of the Alberta decisions citing White Burgess, three of which are criminal cases. ${ }^{197}$ Twenty-four of the decisions, a little more than half, are from the Alberta Court of Queen's Bench. ${ }^{198}$ As mentioned, Justice Renke heard a third of those cases, with the balance heard by other judges, with Justice Veit, Justice Erb, and Justice Graesser deciding two each. Of the 24 in Queen's Bench, 21 are civil cases with seven of those decisions arising from family law matters. Four decisions are from the Provincial Court. In the Court of Appeal, 15 judgments cited White Burgess. The majority are criminal cases, with three civil decisions. ${ }^{199}$

Although applied, White Burgess still does not shine as the guiding light in dealing with the admissibility and use of expert evidence. In many ways, Mohan still rules. Since the

\section{SCC 48.}

See British Columbia (Workers' Compensation Appeal Tribunal) v Fraser Health Authority, 2016 SCC 25 at para 52; Bradshaw, supra note 5 at para 113.

This analysis includes Sandoval-Barillas, supra note 38, wherein the Court mentions the White Burgess decision without citing it and the case does not appear in the headnotes. Also note the search number does not include tribunal decisions.

The actual numbers are 24 criminal law cases with one decision, $R v$ Precision Drilling Ltd, 2016 ABQB 518 , involving quasi-criminal or regulatory offences relating to a fatality at an oilfield with the company charged and convicted under the Alberta Occupational Health and Safety Act, SA 2017, c O-2.1. There are 23 civil law decisions. Supra note 129.

Supra note 29.

2018 ABQB 212 [Paquette].

It should be noted that before his appointment to the Bench, Justice Renke was a professor at the University of Alberta teaching, among other areas, evidence law.

Two of these decisions are from Masters' Chambers.

Arndt, supra note 159, is a Workers' Compensation decision; Prediger, supra note 158, is an appeal of a parenting order; Kon, supra note 28 , is a contractual dispute. 
release of White Burgess, there have been 21 Alberta decisions citing Mohan only, with five of those from the Court of Appeal. Of these 21 decisions, there are several serious criminal cases involving murder charges such as R. v. Vader, ${ }^{200}$ R. v. Newborn, ${ }^{201}$ R. v. Wruck, ${ }^{202}$ and R. v. Ledesma. ${ }^{203}$

The influence of a decision is difficult to discern and may turn on more subtle forms of analysis than a straight numeric count. Still, the numbers do give a picture of the emerging but not-quite-there influence of the newly revised expert evidence regime. Part of the reason may be timing as it has only been three years since the release of the White Burgess decision. An explanation may also be found in the highly influential Mohan decision. Mohan has been the go-to expert evidence case since its release in 1994. Indeed, the decision gave rise to the well-known Mohan criteria. This fact alone suggests the great impact Mohan has on this area of law, particularly when one considers that the Mohan criteria should rightly be labelled the Wigmore criteria. It may take more time, therefore, for White Burgess to take on the heft and credibility of the much-cited Mohan decision. ${ }^{204}$ To do that, the appellate courts must be applying the decision faithfully and resolutely in their appellate review. Moreover, the Supreme Court must embrace the regime to ensure its continuity and influence.

\section{Bringing it All Together: Conclusions ON THE IMPACT OF THE NEW REGIME IN ALBERTA}

The conclusion reached is a hopeful one. The Alberta case analyses reveal that, slowly but surely, the Alberta courts are applying the enhanced expert evidence regime as envisioned in White Burgess. This application, however, is rarely done in a radical fashion. Instead, the trial courts prefer to apply the White Burgess principles to the final probative value of such evidence rather than exclude the evidence at the admissibility stage or even at the gatekeeper stage. Thematically, the recent Alberta cases are concerned mostly with the scope of the expert evidence as opposed to binary admissibility issues. These scope issues are complicated by the new regime's blurring of the traditional lines between opinion evidence and expert evidence. The new principles arising from these recent cases will test those boundaries even further, relaxing admissibility as the definition of expert evidence becomes more pliable. Another trending use of expert evidence is in the area of technology and cyberspace, which will open up new and uncharted areas of expert evidence. In the end, White Burgess impacts softly and perhaps even tentatively, but it does impact.

The trial courts are often the progenitors of change as the appellate courts digest and contemplate the new regime through the dual lens of appellate review and legal principle. In some ways, the lower courts push the innovation factor forward, moving the needle of influence as they apply White Burgess in a variety of factual scenarios. There are glimmers of innovation as the lower courts make steady progress. The recent decision of TWS shows how necessity, novel science, and proof requirements are all intertwined in the White Burgess 
methodology. ${ }^{205}$ In that case, Justice Gates considered the admissibility of expert evidence on the frailty of a child's memory to assist the jury in determining credibility and reliability. The decision is not only innovative in content, but is also an outstanding example of the impact of the full application of the White Burgess legacy. Each step is well-articulated and scrupulously applied. This indeed is the future of White Burgess in 2018 and beyond.

The importance of expert evidence issues must not be underestimated. Expert evidence cuts across all areas of legal practice, raising evidential and trial fairness issues that are at the core of our adversarial system. Here, we must look to our courts to be mindful of the initial admonishment in White Burgess, articulated by Justice Cromwell in the opening paragraph, that "[e]xpert opinion evidence can be a key element in the search for truth, but it may also

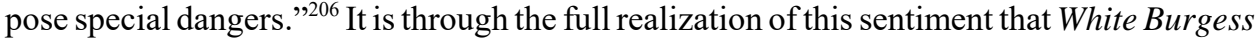
will prove to be an impactful decision in Alberta and across the nation. 